\title{
THE INFLUENCE OF PERCEPTION AND ATTITUDE TOWARD ZAKAT, INFAQ, AND ALMS INTEREST IN OVERCOMING POVERTY LEVELS IN INDONESIA (CASE STUDY IN YOGYAKARTA)
}

Taufik Riza Mahendra', Yuni Sarah², Ghina Fitriani ${ }^{3}$

1,2,3 Muhammadiyah Yogyakarta University

Email: taufikriza86@gmail.com (correspondence)

\begin{abstract}
Zakat, infaq and alms (Sadaqah)are a solution in overcoming the problems of poverty levels and inequality of welfare in Indonesia, which have become problems that continue to be faced today. In Islam, the law for a person to give zakat is obligatory for those who already have assets that reach the nisab in one year. Zakat aims to distribute assets so that there are no social problems, both poverty levels and socioeconomic disparities. Meanwhile, infaq and alms (Sadaqah) in Islam are voluntary. However, if these three activities are carried out on a large scale, it will affect the economic level of a country. The purpose of this research is to see how much someone cares and how much interest is someone in helping other members of society who are less well off and do not have power in the economy. The method used in this research is quantitative-descriptive with multiple linear regression data. The results of the research conducted show that there is an influence of perceptions and attitudes on the interest in zakat, infaq and alms (Sadaqah).
\end{abstract}




\section{Introduction}

The economy is very important for someone in dealing with problems that exist in life. The importance of this economy is to increase the level of welfare. Even economic growth is a measure of a country's success in carrying out economic development. According to Abdullah, economic growth is an increase in per capita output income that occurs continuously for some time and in the long term (Abdullah et al., 2015). So the higher the income per capita, the higher the welfare of the community is expected. One of the problems faced in Indonesia to date concerning welfare issues is the problem of poverty and inequality between community groups. When one of these groups gets richer, there is another group that faces the opposite problem, namely getting poorer. According to Kholid, the poverty rate in the period 2005 - March 2011 decreased by 5.08 million, namely 35.10 million in 2005 to 30.02 million in March 2011 (Kholid, 2018). While the percentage of poor people who were previously in the value of 15.97 percent to 12.49 percent. Even though there was a decrease in the poverty rate which reached $3.48 \%$, this number is still considered high because nearly 30 million people are still included in the poor group or group, while the potential resources they have are very large.

One of the instruments in Islam that has been legalized by the government in terms of regulations and legislation is zakat, infaq and alms (Sadaqah) (ZIS). This instrument is able to slightly solve the problem of social inequality related to welfare in society. The potential for zakat based on research conducted by BAZNAS and the faculty of economics management of IPB in 2011, was able to raise funds that reached 3.4 percent of the total GDP obtained. Or if it is around Rp. 217 trillion each year. Thus, the existence of ZIS is very helpful in providing assistance to the poor, especially in the city of Yogyakarta. However, the problem occurs when how much influence the perceptions and attitudes of the people of Yogyakarta have on their interest in ZIS, it is necessary to further investigate what should be done to increase the amount of zakat, infaq and alms (Sadaqah) (ZIS) received and then distributed to the poor.

BAZNAS (National Zakat Agency) is an official body and the only one established by the government based on Presidential Decree No. RI. 8 of 2001 which has the task and function of collecting and distributing zakat, infaq and alms (ZIS) at the national level. BAZNAS (National Zakat Agency) has a zakat management role as stipulated in Law Number 23 Year 2011, and is declared a non-structural government institution that is independent and accountable to the president through the minister of religion. Fungtion BAZNAS (National Zakat Agency) is (1) Planning for the collection, distribution and utilization of zakat; (2) Implementation of collection, distribution and utilization of zakat; (3) Control of collection, distribution and utilization of zakat; (4) Reporting and accountability for the implementation of zakat management. The authority BAZNAS (National Zakat Agency) is an (1) to collect, distribute, and utilize zakat; (2) Provide recommendations in the formation of the Provincial BAZNAS, Regency / City BAZNAS, and LAZ; (3) Requesting reports on the implementation of zakat, infaq, alms, and other socio-religious 
management from the Provincial BAZNAS and LAZ.

Efforts have always been made by the National Zakat Agency (BAZNAS) DI Yogyakarta in increasing people's insights or muzakki related to zakat, infaq and alms (Sadaqah). This was proven in October 202, the Board of Amil Zakat (BAZNAS) DI Yogyakarta conducted a Foccus Group Discussion with institutions. This activity aims to improve the strengthening of the management of zakat, infaq and alms (Sadaqah) (ZIS) and also increase the effectiveness and efficiency of services.

The institution for collecting zakat, infaq, and alms (Sadaqah) LAZISMU (Muhammadiyah Zakat, Infak, and Sadaqah Institution) Yogyakarta, together with MDMC (Muhammadiyah Disaster Management Center), has distributed disaster assistance in April 2021 with a total of IDR 8,121,779,632 with 298,891 beneficiaries in 18 disaster locations throughout Indonesia. In the amount of IDR 125,600,000 fund. The activities carried out by LAZISMU (Muhammadiyah Zakat, Infak, and Sadaqah Institution) DI Yogyakarta in March 2021 focus on education.

In February 2021 LAZISMU (Muhammadiyah Zakat, Infak, and Sadaqah Institution) Special Region of Yogyakarta has provided assistance to 1,554 beneficiaries of various programs such as economic education, health, social humanity, preaching, and the environment. Tasyaruffan and receipt of these benefits have increased compared to the previous month.

The formulation of the problems in this study include: is there an influence between perceptions and the interest in zakat, infaq and alms (Sadaqah) of the people of Yogyakarta? Is there an influence between attitudes and interest in zakat, infaq and alms (Sadaqah) among the people of Yogyakarta? Do perceptions and attitudes simultaneously influence the interest in tithing, donations and alms of the people of Yogyakarta?

From the formulation of the problem above, this study aims to determine whether there is an effect of perception on interests, attitudes with interests, as well as perceptions and attitudes towards the interest of the people of Yogyakarta in tithing, donations and alms simultaneously. This research is expected to provide benefits both theoretically and managerial. Theoretically, it is hoped that this research will provide new knowledge to readers, including students, lecturers, practitioners, and the general public. Meanwhile, managerial benefits, namely helping to provide input to policy makers related to the development of zakat, infaq and alms (Sadaqah).

This contribution of research is the improved of the scientific methods of way, model and algorithms that research contribution have focused on a reseachers way of developing methods, an improvement more on the originality and novelty of the method being developed in research. So that a contribution that can be taken from this research is applying a method of perception and attitude to the problems of the Islamic philanthropy institutions in a effort to boost zakat, infak, and alms (sadaqah) for to help the poor. 


\section{Literature Review}

\section{Zakat}

In language, zakat means "clean", "developing" and "blessing". In other words, the word zakat can be interpreted as "cleansing", "increasing", "developing" and "being blessed". When interpreted in terms of zakat is an obligation that has been obliged by Allah for every Muslim who has more assets by fulfilling several requirements set by Allah, to be submitted and distributed to the parties entitled to receive it. In addition, zakat is a social and worship obligation, where humans will feel the greatness of the goals of Islamic teachings in the form of loving and helping each other (Abdullah et al., 2015). The law of paying zakat is an obligation of worship which is a consequence of obedience to Allah's commands and its use can help solve economic problems (muamalah) faced by the community. Zakat is obligatory for someone who has reached nifas or a certain limit to get the pleasure of Allah swt.

Issuing zakat fitrah is obligatory for all Muslims in the month of Ramadan which is allocated for eight asnaf, namely those classified as receiving zakat, including indigent, poor, amil, converts, people who have debts, free slaves, ibn sabil and people who travel in the way of Allah. Some of the benefits and lessons of zakat can be stated as follows:

1. Avoiding the social gap between aghniya and dhu 'afa.

2. Tool to purify property and guard against the greed of the wicked.

3. Become an important element in realizing a balance in the distribution of assets (social distribution) and a balance of individual responsibilities in society.

4. Supporting the realization of an Islamic social system consisting of the principles of: ummatanwahidan (one people), musawah (equality), ukhwah Islamiyah (Islamic brotherhood) and tafakulijti ma (shared responsibility).

5. Can purify oneself (person) from the filth of sins, purify the soul and cultivate noble morals and erode hunks (miserly).

6. Zakat is maaliyah worship which has socio-economic dimensions and functions or equal distribution of God's gifts and is also a manifestation of social solidarity, a statement of humanity and justice, and a binder of the unity of the ummah and nation as a mental binder between the rich and the poor and as a hoarder of gaps between the strong and the weak.

7. The existence of zakat fitrah is essentially sharing with other people who are more in need. A high sense of help, with the existence of zakat can also be an instrument in improving the Indonesian economy by reducing poverty.

\section{Infaq}

The word infaq comes from Arabic which literally means al-infad (to spend) or ifna (cessation / extinction) or taqlil (reduction). According to the term figh, the wordinfaq has the meaning of giving part of the assets owned to people who have been instructed by religion to give it such as faqirs, poor, orphans, relatives and others. The terms used in the Koran with regard to infaq include the word : zakat, sadaqah, 
hadyu, jizyah, grants and endowments. So all forms of shopping or giving assets to things that are prescribed by religion can be said to be infaq, whether it is in the form of obligations such as zakat or in the form of sunnah recommendations such as waqf or alms (shadaqah).

\section{Alms}

Alms (Sadaqah) is the gift of an object by someone to another person because they expect the pleasure and reward of Allah swt and does not expect a service fee or replacement. Sadaqoh can also be interpreted as a form of infaq either material or nonmaterial. Sadaqoh is intended for anyone who is desired by those who wish to donate it.

\section{Management of ZISWAF During the Prophet's Period}

Prophet Muhammad saw was sent by Allah swt to straighten human beliefs and morals from the age of ignorance to a better age. Prophet Muhammad saw during his time in Madinah made various developments in various orders not only in the scope of worship. Including muamallah with various contexts, one of which is organizing and developing civilization in economic terms. Prophet Muhammad saw established Baitul Maal as an institution that raises and distributes zakat with amil as an authorized officer. The zakat is obligatory to be performed by Muslims who have fulfilled the nisab and as a means of carrying out the obligation to worship Allah swt.

The management of zakat in the time of Rasulullah saw was very obedient because many of the surahs of the Qur'an explicitly instructed the Prophet to withdraw zakat from a Muslim who had fulfilled the nisab taken by officers who were dedicated to withdrawing zakat in the community. The first thing that was done during the time of Rasulullah in collecting zakat was that the collection was done centrally and handled by the state through the Baitul Maal institution. The direct gathering was led by the Prophet Muhammad saw.

Prophet Muhammad as the leader of the country appointed several shabat as amil who were in charge of collecting zakat and giving part of the zakat to amil as a reward. According to the ulama, the existence of a portion of zakat given to amil is an indication that zakat must be managed by a special officer and not managed by an individual. Rasulullah once sent a young man from the Asad tribe to become an employee who worked to collect zakat from the children of Solomon named Ibn Lutaibah, and had sent Ali bin Abi Talib to Yemen to become amil zakat, according to Yusuf Al-Qardawi, the Prophet Muhammad had sent more than 25 amil to all corners of the country by giving orders to withdraw zakat and distribute it before the amil returns to Medina.

The bookkeeping of zakat is also separated from the opinions obtained by the state from other sources besides zakat. The recording of zakat is also differentiated between income and expenditure, where both must be clearly detailed. Broadly speaking, the prophet drew zakat to society by the state and it was centralized, but the management was still institutionally simple. 


\section{Interest}

According to Slameto, interest is a sense of preference and a sense of attachment to something or activity without being asked. Interest is basically the acceptance of a relationship between oneself and something outside oneself. The stronger or closer the relationship is, the greater the person's interest.

\section{Perceptions}

Perception comes from the Latin perceptio, perceptio is the act of compiling, recognizing and interpreting sensory information in order to provide an overview and understanding of the environment. When you have a mistake in your perception, your understanding of something is also wrong.

Understanding is a behavior that shows a person's ability to grasp the meaning of a concept. Understanding includes the behavior of translating, interpreting, concluding or calculating the concept by using words or other symbols of his own choosing. So, perception and understanding have the same straight line, namely the action or behavior in translating something.

\section{Attitude}

Attitude is also defined as a tendency to approach or avoid, positive or negative towards various social situations, whether it be institutions, personalities, situations, ideas, concepts and so on. The attitude of a person or muzakki in obeying his religious orders in this case is paying zakat, implementing infaq and alms (sadaqah) is a form of a person's feelings towards things he likes or dislikes or a response to things that are not liked, liked or neutral.

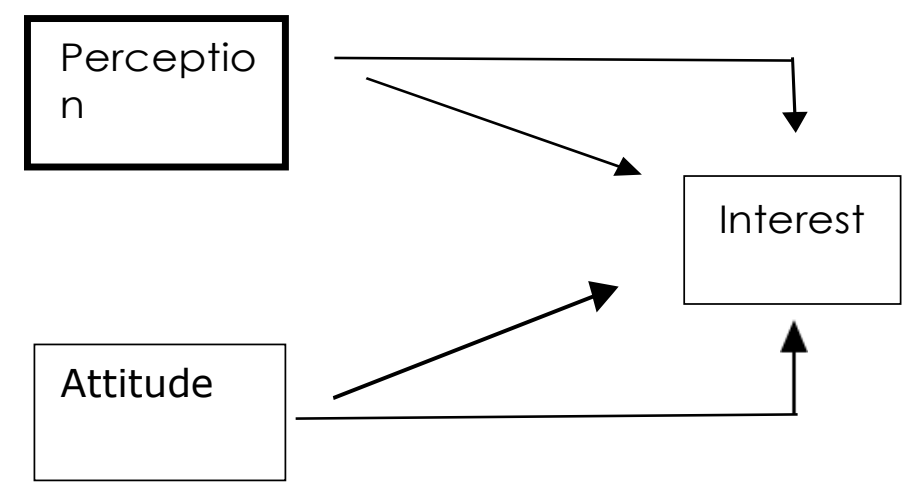

Information:

Perception $=$ Variable $\mathrm{X} 1$

Attitude $=$ Variable $\mathrm{X} 2$

Interests $=$ Variable $Y$

H1 = Partial Test

H2 = Partial Test

H3 = Regression Test

\section{Hypothesis Formulation}


The relationship between perception and interest in zakat

1. Ha: There is influence between perceptions of interest in ZIS in Yogyakarta society

The relationship between attitude and interest

2. Ha: There is an influence between attitudes towards interest in ZIS in the Yogyakarta community

The simultaneous relationship between perceptions and attitudes towards interest

3. Ha: There is a simultaneous influence between perceptions and attitudes towards the ZIS interest of the people of Yogyakarta.

The assumes Reseacher the above because accordimg to the theory in which, by having perception and knowledge of zakat, infak, and alms (Sadaqah) thus providing an image and understanding so that one can zakat, infak, and alms (Sadaqah) with reward and blessing. Reseachers assumes that an attitude can also promote the gathering of zakat, infak, and alms (Sadaqah). Because with this attitude it can be know how a person in the perception of zakat, infak, and alms (Sadaqah) in turn assume perception and attitude can increase interest.

\section{Research Methods}

According to Sugiyono, defines that the research method is a form of scientific activity to obtain data with specific purposes and uses to get an answer to a problem where the scientific method in question is an activity that is rational, empirical and systematic (Sugiyono, 2018). Meanwhile, the method used in this scientific paper is the quantitative method. Quantitative research is a research method based on the positivism philosophy used to examine specific populations or samples, data collection using research instruments, quantitative / statistical data analysis, with the aim of describing and testing predetermined hypotheses (Sugiyono, 2018).

Population is a generalization area consisting of: Objects / Subjects that have certain quantities and characteristics set by the researcher to study and then draw conclusions (Sugiyono, 2018). The population in this study were the people of the Special Region of Yogyakarta. The sample is a member of the population that is considered representative. The size of the sample must reflect the characteristics of the population so that the data obtained is representative. In order to describe precisely the variables under study, the researcher took all the population as the sample. Therefore, sampling in this study uses a saturated sampling method which explains that the saturated sampling method is a sampling technique when all members of the population are used as samples (Sugiyono, 2018). The method used in this study uses the documentation method, namely by recording or collecting notes and reviewing primary data.

$$
Y=\alpha+\beta 1 \log X 1+\beta 2 \log X 2+\beta 3 \log X 3+e
$$

\section{Information:}

$\mathrm{Y}=$ dependent variable

$\mathrm{X}=$ Independent Variable 
$\alpha=$ Constant

$\beta=$ Slope or coefficient estimate

$\mathrm{e}=$ Variable error

The operational definition in the research conducted includes the dependent variable $(\mathrm{Y})$ and the independent variable $(\mathrm{X})$ :

\section{Independent Variable}

The independent variable is the stimulus variable, predictor, antecedent. In Indonesian it is often referred to as an independent variable. Independent variables are variables that affect or influence or cause changes or the emergence of the dependent variable (dependent) (Sugiyono, 2018). In this study, the independent variables $(X)$ include; Perception (X1) and Attitude (X2).

\section{Dependent Variable}

Dependent variables are often referred to as output variables, criteria, consequences. In Indonesian it is often referred to as the dependent variable. The dependent variable is the variable that is affected or that is the result, because of the independent variable. In the research variable $(\mathrm{Y})$ is the people's interest in zakat, infaq and alms (Sadaqah) (Sugiyono, 2018).

Classic linear regression models involve a set of assumptions. Regression is also related to the correlation test. The regression test has a function to predict or predict the value of the $y$ variable when the value of the variable $x$ is added several times. To be able to perform a regression test, of course, you must first perform a correlation test. However, if we do a correlation test, it is not necessarily a regression test. In order to obtain unbiased and efficient thinking values from the regression equation, data analysis must fulfill several classical assumptions of the Normality test, AutoCorrelation test, Heteroscedesticity test, and Multicollinearity test.

Meanwhile, the technique of testing the hypothesis in this study uses linear regression analysis. Linear regression is a type of forecasting or predictive analysis that is often used on quantitative scale data (interval or ratio). The purpose of doing linear regression, among others, is whether a set or set of predictor variables is significant in predicting the response variable. Which predictor variable is significant in explaining the response variable. This is indicated by the regression estimation coefficient. This estimation coefficient will form the regression equation.

Reseacher use the methode because they both study perception or knowledge and ethics or attitude towar one's interest in abolishing religious commands. And the data they used together by quisioners with variable scala liker or variable dummy. So, the single subject or sample can fit into only one category.

\section{Result and Discussions}

\section{Zakat, Infaq, and Alms}

From the annual results issued by BAZNAS Yogyakarta (The national institution for zakat, infaq, and alms Sadaqah Yogyakarta), that the funds collected reached IDR 
4,221,744,777 in 2018 and IDR 4,708,188,632 in 2017. With details:

Table1. Receipt of Zakat Funds

\begin{tabular}{|l|c|c|}
\hline \multicolumn{1}{|c|}{ Receipt of Zakat Funds } & $\mathbf{2 0 1 8}$ & $\mathbf{2 0 1 7}$ \\
\hline Zakat Maal Individually & 3.321 .358 .120 & 3.802 .286 .867 \\
\hline Zakat Maal Institution & 140.500 .000 & 166.800 .000 \\
\hline $\begin{array}{l}\text { Zakat Maal Individually } \\
\text { UPZ }\end{array}$ & 73.132 .157 & 226.468 .865 \\
\hline Zakat Fitrah & 46.754 .500 & 53.316 .400 \\
\hline Zakat Fitrah UPZ & 640.000 .000 & 459.316 .500 \\
\hline & & 4.708 .188 .632 \\
\hline
\end{tabular}

As for the distribution of zakat made by BAZNAS Yogyakarta (The national institution for zakat, infaq, and Sadaqah Yogyakarta) in 2018 amounted to IDR 4,241,804,479 and in 2017 amounted to IDR 4,749,690,100. with details:

Table 2 Distribution of Zakat Funds

\begin{tabular}{|l|c|c|}
\hline \multicolumn{1}{|c|}{$\begin{array}{c}\text { Distribution of Zakat } \\
\text { Funds }\end{array}$} & $\mathbf{2 0 1 8}$ & $\mathbf{2 0 1 7}$ \\
\hline Zakat for the Poor & 2.164 .526 .500 & 2.757 .715 .100 \\
\hline Zakat for Convert & 30.000 .000 & 28.000 .000 \\
\hline Zakat for Fisabilillah & 983.379 .000 & 860.715 .700 \\
\hline Zakat for Amil & 371.173 .979 & 417.473 .935 \\
\hline Zakat for UPZ & 692.725 .000 & 685.785 .350 \\
\hline & 4.241 .804 .479 & \\
\hline Total & & \\
\hline
\end{tabular}

Infaq and alms funds that can be collected by the DIY BAZNAS (The national institution for zakat, infaq, and sadaqah Yogyakarta) Institute are IDR 1,117,635,529 with a distribution of IDR 465,894,514 for the distribution of infaq and tied alms or muqayadah and IDR 638,913,046 on the distribution of infaq and free alms (Sadaqah) or mutlaqah in 2018. In 2017 BAZNAS DIY (The national institution for zakat, infaq, and sadaqah Yogyakarta) received infaq and alms (Sadaqah) funds of IDR 915,034,416 with the distribution of infaq and tied alms (Sadaqah) of IDR 225,911,500 and the distribution of infaq and unrestricted alms (Sadaqah) of IDR 350,571,000.

Table 3 Receiving and Distribution of Infaq and Alms Funds 


\begin{tabular}{|l|c|c|}
\hline \multicolumn{1}{|c|}{ Infak and Alms Funds } & $\mathbf{2 0 1 8}$ & $\mathbf{2 0 1 7}$ \\
\hline Reception & 1.117 .635 .529 & 915.034 .416 \\
\hline Channeling Bond & 465.894 .514 & 225.911 .500 \\
\hline Unbound Distribution & 638.913 .046 & 350.571 .000 \\
\hline
\end{tabular}

The Zakat, Infaq and Alms (Sadaqah) funds are collected by BAZNAS (The national institution for zakat, infak, and sadaqah) together with zakat institutions and UPZ (Zakat Collection Unit) which are recorded in the annual book on December 31 2018.

\section{Multiple Linear Regresion}

Table 4. Model Summary (Zakat Regression Test) Model Summary ${ }^{b}$

\begin{tabular}{|l|l|l|l|l|}
\hline Model & $\mathrm{R}$ & R Square & $\begin{array}{l}\text { Adjusted } \mathrm{R} \\
\text { Square }\end{array}$ & $\begin{array}{l}\text { Std. Error of } \\
\text { the Estimate }\end{array}$ \\
\hline 1 & $.429 \mathrm{a}$ & .184 & .126 & 2.093 \\
\hline
\end{tabular}

a. Predictors: (Constant), zakat attitude, zakat perception

b. Dependent variable: interest in zakat

From the model summary, it shows that the Adjusted R Square is 0.126 . So it means that $12.6 \%$ of the variation in a person's interest in zakat is explained by attitudes and perceptions. Meanwhile, the remaining $97.4 \%$ is explained by other variables not included in the model.

Table 5 ANOVA (zakat regression test)

\begin{tabular}{|l|l|r|r|r|r|c|}
\hline \multirow{4}{*}{\begin{tabular}{l} 
Model \\
\multirow{2}{*}{1}
\end{tabular}} & $\begin{array}{c}\text { Sumof } \\
\text { Squares }\end{array}$ & df & $\begin{array}{r}\text { Mean } \\
\text { Square }\end{array}$ & F & Sig. \\
\cline { 2 - 8 } & Regression & 44.833 & 2 & 22.416 & 4.369 & $.018^{\mathrm{b}}$ \\
\cline { 2 - 8 } & Residual & 241.167 & 47 & 5.131 & & \\
\cline { 2 - 8 } & Total & 286.000 & 49 & & & \\
\hline
\end{tabular}

a. Dependent Variable: interest

b. Predictors: (Constant), attitude, perception

From the ANOVA test, it was obtained a significant value of 0.018 below 0.05 . Thus the perception and attitude variables collectively affect a person's interest in giving and giving alms (Sadaqah). 
Table 6 Multiple Linear Regression Test (Zakat Regression Test)

Coefficients $^{\mathrm{a}}$

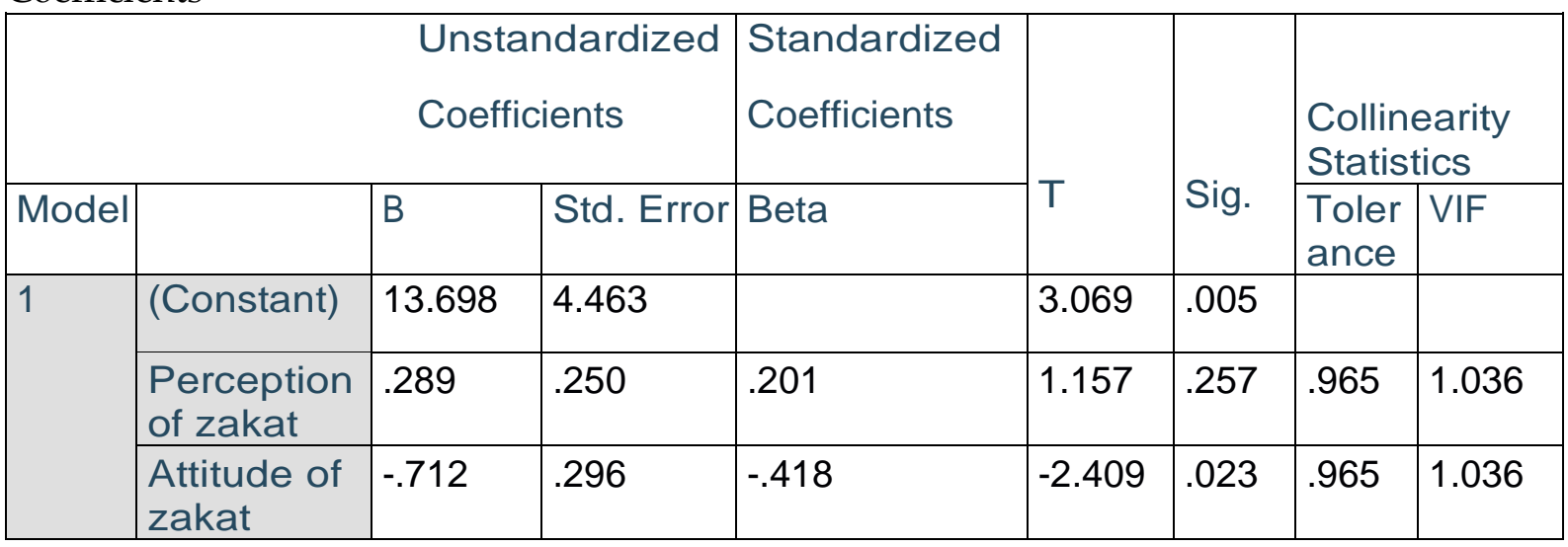

a. Dependent Variable: interest in zakat

Based on the results of the $t$ test, it can be seen that the perception variable does not affect someone's interest in zakat. Meanwhile, attitudes have a negative and significant influence on the interest in zakat and practice it. With a significant level 0.005 , it can be concluded that the two variables simultaneously still influence the interest in zakat and zakat their assets.

Table 7 Model Summary (Regression test of infaq and alms)

Model Summary ${ }^{\mathrm{b}}$

\begin{tabular}{|l|l|l|l|l|}
\hline Model & $R$ & R Square & $\begin{array}{l}\text { Adjusted R } \\
\text { Square }\end{array}$ & $\begin{array}{l}\text { Std. Error of } \\
\text { the Estimate }\end{array}$ \\
\hline 1 & $.521^{\mathrm{a}}$ & .271 & .219 & 2.306 \\
\hline
\end{tabular}

a. Predictors: (constant), infaq and alms attitude, infaq and alms perceptions

b. Dependent Variable: interet in infaq and alms

The model summary shows that the Adjusted R Square is 0.219 . Thus, it means that $21.9 \%$ of the variation in a person's interest in giving and giving alms is influenced by perceptions and attitudes. Meanwhile, the remaining $78.1 \%$ is explained by other variables not included in the model.

Table 8 ANOVA Test (Regression Test of Infaq and Alms)

ANOVA $^{a}$

\begin{tabular}{|l|l|l|l|l|l|l|}
\hline \multirow{2}{*}{ Model } & & $\begin{array}{l}\text { Sum } \\
\text { Squares }\end{array}$ & Df & Mean Square & F & Sig. \\
\hline 1 & Regression & 55.462 & 2 & 27.731 & 5.214 & $.012^{\mathrm{b}}$ \\
\cline { 2 - 7 } & Residual & 148.926 & 28 & 5.319 & & \\
\cline { 2 - 7 } & Total & 204.387 & 30 & & & \\
\hline
\end{tabular}

a. Dependent Variable: interest in infaq and alms

b. Predictors: (constant), attitude of infaq and alms, perception of infaq and alms 
From the ANOVA test, it was found that F count was 5.214 and it was significant below 0.05 . Thus the perception and attitude variables collectively affect a person's interest in giving and giving alms.

Table 9. Multiple Linear Regression Test (Infaq and Alms Regression Test)

Coefficients $^{\mathrm{a}}$

\begin{tabular}{|c|c|c|c|c|c|c|c|c|}
\hline \multicolumn{4}{|c|}{ Unstandardized Coefficients } & \multirow{2}{*}{ 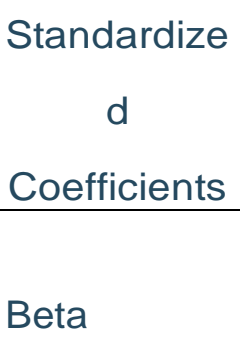 } & \multirow[b]{2}{*}{$\mathrm{T}$} & \multirow[b]{2}{*}{ Sig. } & \multicolumn{2}{|c|}{$\begin{array}{l}\text { Collineari } \\
\text { ty } \\
\text { Statistics }\end{array}$} \\
\hline Model & & B & $\begin{array}{l}\text { Std. } \\
\text { Error }\end{array}$ & & & & $\begin{array}{l}\text { Tolera } \\
\text { Nce }\end{array}$ & VIF \\
\hline \multirow[t]{3}{*}{1} & (Constant) & 20.641 & 4.378 & & 4.715 & .000 & & \\
\hline & $\begin{array}{l}\text { Perception of } \\
\text { infak and } \\
\text { Almighty }\end{array}$ & -.643 & .544 & -.334 & -1.183 & 247 & .327 & 3.056 \\
\hline & $\begin{array}{l}\text { Attitude of infak } \\
\text { and almighty }\end{array}$ & -.427 & .570 & -.211 & -.749 & .460 & .327 & 3.056 \\
\hline
\end{tabular}

a. Dependent Variable: Interest of infaq and alms

Based on the results of the $t$ test, it can be seen that the perception variable does not affect someone's interest in zakat. Meanwhile, attitudes have a negative and significant influence on the interest in zakat and practice it. With a significant level of 0.05 , it can be concluded that the two variables simultaneously still have an effect on the interest in giving away and giving away their assets.

BAZNAS Yogyakarta City in trying to improve the strengthening of the management of LAZ, Takmir Masjid, and Islamic Religious Institutions in this case is effectiveness and efficiency in services to muzakki. The effect of this strengthening is that in January 2021, it was recorded as IDR 131,145,000 from the total collection of IDR 387,791,187. The funds that have been collected are used to help victims of disasters such as earthquakes, floods, landslides in Jabar (West Java), Sulbar (West Sulawesi) and Kalsel (South-East of kalimantan) worth IDR 30,000,000, ready-to-eat food assistance for cleaners, pedicab drivers etc. worth IDR 90,000,000, wastapel assistance for 5 Islamic boarding school and Thermogun for Mustaqim Kotagede mosque.

\section{Conclusion}

Based on the results of the analysis and discussion in this study, several conclusions were obtained:

1. From the results of data processing that has been done independently, that the perception does not affect the interest of the people of Yogyakarta in 
giving zakat. This is obtained from data processing which shows a significant level of 0.257. while the attitude of the people affects the interest of the people of Yogyakarta in zakat. This is known from the significance level of data processing which shows 0.023 .

2. Simultaneously, the perceptions and attitudes of the people of Yogyakarta influence their interest in giving zakat.

3. In donation and almsgiving, neither the perception nor the attitude of the people of Yogyakarta has an effect on giving one's interest in tithing.

4. However, on the regression test. Resulting in that the attitudes and perceptions of the community simultaneously influence the interest of the community in giving donations and alms.

At the end of this research, there are several suggestions aimed at managing zakat, infaq and alms later:

1. In terms of muzakki's trust in LAZ Institution, it is still lacking. Given the data results that have not shown a very significant level. So this requires guidance by the Institution in addition to inviting people to pay zakat, donations and alms. But it also provides knowledge about obtaining financial reports. So as to increase the public's trust in LAZ Institution.

2. Because there are still people who do not get information about zakat, infaq and alms (Sadaqah). So that LAZ agency must also provide education both general knowledge and benefits. Regarding this, it can be done either during the Friday prayer sermon, cult, religious education schools, or other facilities that are able to broaden people's insights regarding zakat, donations and alms.

\section{References}

[1]Abdullah, N., Derus, A. M., \& Al-Malkawi, H. A. N. (2015). The effectiveness of zakat in alleviating poverty and inequalities a measurement using a newly developed technique. Humanomics, 31(3), 314-329. https://doi.org/10.1108/H-022014-0016

[2]Anggraini, R., Ababil, R., \& Widiastuti, T. (2018). Pengaruh Penyaluran Dana ZIS dan Tingkat Inflasi terhadap Pertumbuhan Ekonomi Indonesia Periode 20112015. FALAH: Jurnal Ekonomi Syariah. https://doi.org/10.22219/jes.v3i2.7231

[3]Arsyad, lincolin. (2015). ekonomi pembangunan edisi 5. Ekonomi Pembangunan.

[4]BAZNAS Kota Yogyakarta. (2018). Laporan Keuangan Dan Laporan Aditor Independen. BAZNAS Kota DI Yogyakarta

[4] Beik, I. S., \& Arsyianti, L. D. (2016). Ekonomi Pembangunan Syariah. Rajawali Press.

[5]Beik, Irfan Syauqi. 2013. Economic Role of Zakat in Reducing Poverty and Income Inequality: A Case Study in the Province of DKI Jakarta, Indonesia. LAP Lambert Academic Publishing.

[6]Chaudhry, Muhammad Sharif. 2012. “Islamic Economic System Basic Principles 
(Translation) (Sistem Ekonomi Islam Prinsip Dasar (Terjemahan))." Jakarta: Penerbit Kencana.

[7] Firdaus, M., Beik, I. S., Irawan, T., \& Juanda, B. (2012). Economic estimation and determinations of Zakat potential in Indonesia. IRTI Working Paper Series.

[8]Hany, Ira Humaira, and Dina Islamiyati. "Pengaruh Zis Dan Faktor Makro Ekonomi Terhadap Tingkat Kemiskinan Di Indonesia." Jurnal Ekonomi 25, no. 1 (2020): 118-31.

[9]Huda, Nurul. 2012. Islamic Public Finance: A Theoretical and Historical Approach (Keuangan Publik Islami: Pendekatan Teoritis Dan Sejarah). Prenada Media.

[10]Johari, F., Ali, A. F. M., \& Aziz, M. R. A. (2018). The Role of Zakat and Success Factor for Muallaf Conditions: An Analysis in Selangor, Malaysia. 'Ulum Islamiyyah the Malaysian Journal of Islamic Sciences.

[11]Khairina, N. (2019). Analisis Pengelolaan Zakat, Infak, Dan Sedekah (ZIS) Untuk Meningkatkan Ekonomi Duafa (Studi Kasus di Lembaga Amil Zakat Nurul Hayat Cabang Medan ). AT-TAWASSUTH: Jurnal Ekonomi Islam. https://doi.org/10.30821/ajei.v4i1.4091

[12]Nur Kholid, A. (2018). Dampak Zakat, Infak Dan Sedekah (Zis) Terhadap Penurunan Tingkat Kemiskinan Dan Percepatan Pengentasan Kemiskinan. Jurnal Bina Ummat: Membina Dan Membentengi Ummat. Https://Doi.Org/10.38214/Jurnalbinaummatstidnatsir.V1i02.22

[13] Lapopo, J. (2017). PENGARUH ZIS (ZAKAT, INFAK, SEDEKAH) DAN ZAKAT FITRAH TERHADAP PENURUNAN KEMISKINAN DI INDONESIA PERIODE 1998 - 2010. Media Ekonomi. https://doi.org/10.25105/me.v20i1.779

[14] Mintarti, N. 2009. “Indonesia Zakat and Development Report.” Jakarta.

[15] Rosyidi, Suherman. 2012. "Introduction to Economic Theory Approaches to Micro \& Macroeconomic Theory (Pengantar Teori Ekonomi Pendekatan Kepada Teori Ekonomi Mikro \& Makro)." Jakarta: Rajawali Pers.

[16]Sugiyono, D. (2018). Metode penelitian kuatintatif, kualitatif dan R \& D / Sugiyono. In Bandung: Alfabeta.

[17]Suma, M. A. (2015). Zakat, Infak, dan Sedekah: Modal dan Model Ideal Pembangunan Ekonomi dan Keuangan Modern. Al-Iqtishad: Journal of Islamic

[18]Syofian Siregar. (2013). Statistika parametrik untuk penelitian kuantitatif. In Bumi aksara.

[19] Lazismu.or.id acceessed on Thursday, 29 April 2021 at 21.00 WIB.

[20] baznas.jogjakarta.go.id accessed on Thursday, 29 April 2021 at 22.00 WIB. 